\title{
Sprouting, phenology, and maturation of the Italian grapevine 'Fiano' in Campo Largo, PR, Brazil
}

\author{
Brotação, fenologia e maturação da videira italiana 'Fiano' em \\ Campo Largo, PR, Brasil
}

\author{
João Guilherme Fowler ${ }^{1}$; Gislâine Margoti ${ }^{1}$; Luiz Antonio Biasi ${ }^{2 *}$
}

\section{Highlights:}

The Italian cultivar Fiano is productive and adapted to the region of Campo Largo.

Sprouting of dormant buds can be increased with Erger in years of low chill.

Wine production in the altitude region in the Paraná State may be a new economical option.

\begin{abstract}
Despite the expansion of viticulture in Brazil, the lack of chilling hours is a factor that requires the use of growth inducers to promote sprouting. Erger ${ }^{\mathrm{TM}}$ is a product of low toxicity and efficient in the bud induction of apple. However, there is a lack of studies testing such a product on the grapevine. This research was carried out to evaluate the sprouting and phenological cycle of 'Fiano' grapevine after Erger ${ }^{\mathrm{TM}}$ and calcium nitrate application in comparison to hydrogen cyanamide, as well as characterizing its production in Brazil. The experiment was carried out in Campo Largo, PR, under a trellis system, with plants spaced at $1.25 \times 2.7$ meters. The experimental design was a randomized complete block design with four replications and three plants per plot. Different concentrations of Erger ${ }^{\mathrm{TM}}$ and calcium nitrate $\left(3 \%, 5 \%, 7 \%\right.$, and control) were tested compared to the standard dose of Dormex ${ }^{\mathrm{TM}}(4 \%)$ to induce sprouting in 'Fiano' grapevine, while phenological aspects of this cultivar were evaluated following the $\mathrm{BBCH}$ scale. Soluble solids content, titratable acidity, and $\mathrm{pH}$ were evaluated weekly after the beginning of berry maturation. The main biometric and qualitative characteristics of bunches were evaluated at harvest. All treatments presented satisfactory sprouting rates in 2014, but a lower cold accumulation was observed in 2015, and Erger ${ }^{\mathrm{TM}}$ application significantly increased sprouting when compared to the control. Plants treated with Erger ${ }^{\mathrm{TM}}$ had a delay in sprouting in the two years of study, requiring more time to reach a satisfactory percentage of open buds. The anticipation of sprouting was also observed in all treatments in the second agricultural season due to higher temperatures in relation to the previous year when the occurrence of low temperatures led to a longer time to start bud opening, which was related to ecodormancy. The cultivar Fiano is productive and adapted to the conditions of Campo Largo, PR, Brazil.
\end{abstract}

Key words: Vitis vinifera. Dormancy. Hydrogen cyanamide.

\section{Resumo}

Apesar da expansão da viticultura no Brasil, a falta de horas de frio é um fator que obriga o uso de indutores de crescimento para promover a brotação. $\mathrm{O}$ Erger $^{\circledR}$ é um produto de baixa toxicidade e

${ }^{1}$ Discentes, Programa de Pós-Graduação em Agronomia-Produção Vegetal, PGAPV, Universidade Federal do Paraná, UFPR Curitiba, PR, Brasil. E-mail: joaofowler@gmail.com; gislainemargoti@gmail.com

2 Prof., UFPR, Curitiba, PR, Brasil. E-mail: biasi@ufpr.br

"Author for correspondence 
eficiente na indução de brotação de macieira, no entanto, há carência de trabalhos testando tal produto com videira. Esta pesquisa foi realizada com o objetivo de avaliar a brotação e o ciclo fenológico da videira 'Fiano' após aplicação de Erger ${ }^{\circledR}$ e nitrato de cálcio em comparação com a cianamida hidrogenada e caracterizar a produção desta cultivar no Brasil. O experimento foi realizado num parreiral localizado em Campo Largo-PR, conduzido em sistema de espaldeira, com plantas espaçadas em 1,25 x 2,7 metros. O delineamento experimental utilizado foi em blocos ao acaso, com 4 repetições e 3 plantas por parcela, onde foram testadas diferentes concentrações de Erger $^{\circledR}$ e nitrato de cálcio (3\%, 5\%,7\% e testemunha) comparadas à dose padrão de $\operatorname{Dormex}^{\circledR}(4 \%)$ para induzir a brotação de videiras da cultivar Fiano, além de acompanhar aspectos fenológicos seguindo a escala BBCH. Após o início da maturação das bagas, foi avaliado semanalmente o teor de sólidos solúveis, a acidez titulável e o $\mathrm{pH}$. Na colheita foram avaliadas as principais características biométricas e qualitativas dos cachos. Observaram-se taxas de brotação satisfatórias em todos os tratamentos em 2014, mas em 2015 houve menor acúmulo de frio e a aplicação de Erger $^{\circledR}$ aumentou significativamente a brotação em relação a testemunha. Nos dois anos de estudo, as plantas tratadas com $\operatorname{Erger}^{\circledR}$ sofreram um atraso na brotação, exigindo mais tempo para atingir uma porcentagem satisfatória de gemas abertas. Também foi observada uma antecipação da brotação em todos os tratamentos na segunda safra em virtude de temperaturas mais elevadas em relação ao ano anterior, quando a ocorrência de temperaturas baixas ocasionou maior tempo para iniciar a abertura de gemas em decorrência da instalação de uma ecodormência. A cultivar Fiano é produtiva e adaptada as condições de Campo Largo, PR, Brasil.

Palavras-chave: Vitis vinifera. Dormência. Cianamida hidrogenada.

\section{Introduction}

Brazilian production of grapes in 2017 was 1,912,034 tons (Food and Agriculture Organization [FAO], 2019). Distributed in a very extensive area of the country, Brazilian viticulture is very diverse and subject to the fluctuation of climate factors, which strongly affect production. The little cold was registered during the winter of 2016, anticipating the sprouting, which occurred in the late frost, causing a drastic reduction of production in southern Brazil, which is the main producing region. This fact led to a $34.7 \%$ reduction in national grape production (Mello, 2017).

The cultivation of Vitis vinifera grapevines has grown in the south region, driven by the interest of wineries that started producing and exporting better quality wines. The production of fine wines reached $37,148,982$ liters in 2015 , with increases of 36.69 and $39.04 \%$ in exports of sparkling wines and wines in 2016, respectively (Mello, 2017). New vineyards have been installed in regions considered of high altitude, above $900 \mathrm{~m}$, which present better climate conditions for the production of grapes of superior quality for winemaking (Malinovski et al., 2012;
Vianna, Massignan, Pandolfo, Dortzbach, \& Vieira, 2016; Würz et al., 2017), especially in the states of Santa Catarina and Paraná. Among the cultivars in production are those of French origin, such as Cabernet Sauvignon, Merlot, Sauvignon Blanc, Pinot Noir, and Chardonnay. However, Italian cultivars that have been recently introduced have been standing out and expanding their cultivation, such as Nebbiolo, Vermentino, Verdicchio, Sangiovese, Sagrantino, and Montepulciano (Brighenti, Silva, Brighenti, Porro, \& Stefanini, 2014; Allebrandt et al., 2017). Fiano cultivar has also aroused interest in the production of white wines (Malinovski, Vieira, Campos, Stefanini, \& Silva, 2016; Brighenti et al., 2017).

Adaptation of cultivars to the climate of these regions is fundamental to make their cultivation viable. The accumulation of chilling hours during dormancy is an important factor to allow the vine to sprout properly and present a regular and uniform cycle. In many regions of Brazil, viticulture was implanted in places that do not have enough number of chilling hours to meet the requirement of the cultivars. Therefore, the chemical application of sprouting inductors is necessary, being hydrogen 
cyanamide the main product used for this purpose. However, due to its high toxicity and risk of intoxication to the applicator, other products have been tested to find a substitute with the same functionality and lower toxicity (Botelho, Pavanello, Pires, Terra, \& Muller, 2007; Bueno, Villa, Rosa, \& Stumm, 2017).

Erger ${ }^{\mathrm{TM}}$ is a biostimulant compound based on inorganic nitrogen, monosaccharides, polysaccharides, and diterpenes, which presented good results for apple dormancy breakdown when associated with calcium nitrate (Hawerroth, Petri, Leite, \& Herter, 2010). Thus, it could also possibly stimulate grapevine buds, as it already affects apple.

This study aimed to evaluate the sprouting and phenological cycle of 'Fiano' grapevines after Erger ${ }^{\mathrm{TM}}$ and calcium nitrate application in comparison to hydrogen cyanamide and characterize its production in Campo Largo, Paraná State, Brazil.

\section{Material and Methods}

\section{Experiment site}

The experiment was conducted at Vinícola Legado, located in Campo Largo, PR, Brazil $\left(25^{\circ} 23^{\prime} 46.3^{\prime \prime} \mathrm{S}\right.$ and $\left.49^{\circ} 30^{\prime} 09.6^{\prime \prime} \mathrm{W}\right)$. This region is characterized by an altitude of 976 meters above sea level and inserted in the $\mathrm{Cfb}$ climate according to Köppen classification, with well-defined winters and summers, precipitation distributed over the year, and the possibility of severe frosts.

\section{Vineyard characteristics}

The vineyard was implanted in a trellis conduction system with three wires, in which the first one is distant $1.2 \mathrm{~m}$ from the ground. Vines were grafted onto the 'Paulsen 1103' rootstock, spaced $1.25 \mathrm{~m}$ between plants and $2.70 \mathrm{~m}$ between rows. Plants were Guyot pruned with four long canes, two of them arched to the right and two to the left. Pruning was carried out on August 2, 2014, and August 10, 2015, followed by the application of sprouting inducers on August 5, 2014, and August 14, 2015. Fungicide applications were performed according to the need in each cycle.

\section{Application of treatments}

Treatments consisted of 3\% Erger ${ }^{\mathrm{TM}}+3 \%$ calcium nitrate, $5 \%$ Erger $^{\mathrm{TM}}+5 \%$ calcium nitrate, $7 \%$ Erger $^{\mathrm{TM}}+7 \%$ calcium nitrate, $4 \%$ Dormex $^{\mathrm{TM}}$, and control. These products were sprayed to the point of draining on the buds. Plants of other treatments were covered with black plastic during the application of treatments.

\section{Assessments}

The percentage of sprouted buds at the $\mathrm{BBCH} 07$ stage was evaluated in two canes per plant, one to the right and another to the left. Sprout evaluation was performed weekly from the $28^{\text {th }}$ day after application (DAA) to $62^{\text {nd }}$ DAA in the $2014 / 2015$ cycle and $14^{\text {th }}$ DAA to $49^{\text {th }}$ DAA in the $2015 / 2016$ cycle.

The phenological development was also evaluated in the same canes marked for sprout analysis in the three distal buds of each stem, totaling six buds per plant since they are more fertile in relation to basal buds (Dry, 2000). Considering the BBCH scale proposed by Lorenz et al. (1995), the time of occurrence of the phenological stages $\mathrm{BBCH}$ 07 (beginning of bud burst: green shoot tips just visible), BBCH 53 (inflorescence clearly visible), $\mathrm{BBCH} 65$ (full flowering: $50 \%$ of flowerhoods fallen), BBCH 71 (fruit set: fruits begin to swell, remains of flowers lost), $\mathrm{BBCH} 75$ (berries peasized), $\mathrm{BBCH} 81$ (beginning of ripening: berries begin to brighten in color), and $\mathrm{BBCH} 89$ (berries ripe for harvest) was determined. Changes in the phenological stage were determined when there was an alteration in three buds or more per plant. 
Hourly temperatures provided by the Paraná Meteorological System (SIMEPAR) from the weather station in Lapa, PR, which is the closest station, $48 \mathrm{~km}$ far from Campo Largo, PR, were used for the calculation of chilling hours $(\mathrm{CH})$.

The number of degree-days of each phenological stage was calculated by the equations proposed by Villa Nova, Pedro, Pereira, and Ometto (1972).

$$
\begin{aligned}
& \mathrm{DD}=(\mathrm{Tm}-\mathrm{Tb})+(\mathrm{TM}-\mathrm{Tm}) / 2, \text { if } \mathrm{Tm}>\mathrm{Tb} \\
& \mathrm{DD}=(\mathrm{TM}-\mathrm{Tb})^{2} / 2(\mathrm{TM}-\mathrm{Tm}), \text { if } \mathrm{Tm}<\mathrm{Tb} \\
& \mathrm{DD}=0, \text { if } \mathrm{TM}<\mathrm{Tb}
\end{aligned}
$$

In which:

DD: degree-days

TM: daily maximum temperature $\left({ }^{\circ} \mathrm{C}\right)$

Tm: daily minimum temperature $\left({ }^{\circ} \mathrm{C}\right)$

$\mathrm{Tb}$ : base temperature $\left(10^{\circ} \mathrm{C}\right)$

Samples were collected weekly from the veraison stage to determine the soluble solids content with a manual refractometer, $\mathrm{pH}$, and titratable acidity according to the methodology of the Instituto Adolfo Lutz (2008). Forty berries were collected from the base, medium, and top of bunches for each sample.

The following characteristics were evaluated when bunches were harvested: number of bunches per plant, bunch weight $(\mathrm{g})$, bunch yield per plant $(\mathrm{kg})$, bunch width $(\mathrm{cm})$, bunch length $(\mathrm{cm})$, number of berries per bunch, berry weight $(\mathrm{g})$, percentage of rachis $(\%)$, berry width $(\mathrm{cm})$, berry length $(\mathrm{cm})$, number of seeds per berry, seed weight per berry (mg).

\section{Experimental design and statistical analysis}

The treatments were distributed in a randomized complete block design, with five treatments, four replications, and three plants per plot (useful central plant). The results were submitted to the Bartlett test to verify the homogeneity of variances of treatments, and the Kruskal Wallis test was used to verify the normality of the data. Subsequently, an analysis of variance was performed, and the Scott Knott test at 5\% was used to compare the means of treatments. All tests were performed using the statistical software Assistat ${ }^{\mathrm{TM}}$.

\section{Results and Discussion}

Treatments showed similar sprouting of 'Fiano' grapevine in both evaluated years. The application of Erger ${ }^{\mathrm{TM}}+$ calcium nitrate at all concentrations caused a delay of sprouting, which was significantly different from the treatment with Dormex ${ }^{\mathrm{TM}}$ and control in the evaluations performed at 28 and 34 days after application in the first year (Table 1). This difference remained until 48 days after application, but only at the highest concentration of Erger ${ }^{\mathrm{TM}}$ and calcium nitrate $(7 \%)$. No difference was observed between treatments in the following evaluations.

No significant difference was observed between treatments in the second year of evaluation, but the percentages of sprouting in treatments with Erger ${ }^{\mathrm{TM}}$ were lower when compared to treatments with Dormex ${ }^{\mathrm{TM}}$ and control in the evaluations performed at 20 and 27 days after application. The highest concentration of Erger ${ }^{\mathrm{TM}}$ and calcium nitrate (7\%) showed similar results to those of the last year. A lower percentage of sprouting was observed until 35 days after application when it was $75.8 \%$ with this treatment and higher than $80 \%$ in the others (Table 1). The control was inferior to the others at 48 days after application, with $85.2 \%$ of sprouting, while the other treatments did not differ and presented sprouting higher than $94 \%$. 
Table 1

Percentage of buds sprouted of 'Fiano' grapevine in 2014 and 2015 under Erger'TM and Dormex ${ }^{\mathrm{TM}}$ effect $^{\mathrm{TM}}$

\begin{tabular}{|c|c|c|c|c|c|c|}
\hline & Date - DAA & Date - DAA & Date - DAA & Date - DAA & Date - DAA & Date - DAA \\
\hline Treatment & $\begin{array}{c}09 / 02 / 2014 \\
28 \text { days }\end{array}$ & $\begin{array}{c}09 / 08 / 2014 \\
34 \text { days }\end{array}$ & $\begin{array}{c}09 / 15 / 2014 \\
41 \text { days }\end{array}$ & $\begin{array}{c}\text { 09/22/2014 } \\
48 \text { days }\end{array}$ & $\begin{array}{c}\text { 09/29/2014 } \\
55 \text { days }\end{array}$ & $\begin{array}{c}10 / 06 / 2014 \\
62 \text { days }\end{array}$ \\
\hline Control & $60.8 \mathrm{a}$ & $83.9 \mathrm{a}$ & $95.0 \mathrm{a}$ & $95.0 \mathrm{a}$ & $92.8 \mathrm{a}$ & $94.6 \mathrm{a}$ \\
\hline $\mathrm{E} 3 \%+\mathrm{CN} 3 \%$ & $26.3 \mathrm{~b}$ & $60.0 \mathrm{~b}$ & $93.7 \mathrm{a}$ & $100.0 \mathrm{a}$ & $100.0 \mathrm{a}$ & $100.0 \mathrm{a}$ \\
\hline $\mathrm{E} 5 \%+\mathrm{CN} 5 \%$ & $28.4 \mathrm{~b}$ & $57.6 \mathrm{~b}$ & $96.2 \mathrm{a}$ & $98.3 \mathrm{a}$ & $98.3 \mathrm{a}$ & $98.3 \mathrm{a}$ \\
\hline $\mathrm{E} 7 \%+\mathrm{CN} 7 \%$ & $7.9 \mathrm{~b}$ & $43.0 \mathrm{~b}$ & $67.6 \mathrm{~b}$ & $78.5 \mathrm{~b}$ & $84.0 \mathrm{a}$ & $87.3 \mathrm{a}$ \\
\hline Dormex ${ }^{\mathrm{TM}}$ & $82.5 \mathrm{a}$ & $87.9 \mathrm{a}$ & $90.1 \mathrm{a}$ & $95.8 \mathrm{a}$ & $95.6 \mathrm{a}$ & $95.2 \mathrm{a}$ \\
\hline $\mathrm{CV} \%$ & 45.59 & 23.71 & 5.4 & 8.4 & 8.46 & 6.87 \\
\hline Treatment & $\begin{array}{c}08 / 27 / 2015 \\
13 \text { days }\end{array}$ & $\begin{array}{c}09 / 03 / 2015 \\
20 \text { days }\end{array}$ & $\begin{array}{c}\text { 09/10/2015 } \\
27 \text { days }\end{array}$ & $\begin{array}{c}09 / 18 / 2015 \\
35 \text { days }\end{array}$ & $\begin{array}{c}\text { 09/23/2015 } \\
40 \text { days }\end{array}$ & $\begin{array}{c}10 / 01 / 2015 \\
48 \text { days }\end{array}$ \\
\hline Control & $8.5 \mathrm{a}$ & $52.2 \mathrm{a}$ & $79.4 \mathrm{a}$ & $80.7 \mathrm{a}$ & $79.6 \mathrm{a}$ & $85.2 \mathrm{~b}$ \\
\hline $\mathrm{E} 3 \%+\mathrm{CN} 3 \%$ & $7.3 \mathrm{a}$ & $32.7 \mathrm{a}$ & $72.3 \mathrm{a}$ & $90.8 \mathrm{a}$ & $94.6 \mathrm{a}$ & $96.4 \mathrm{a}$ \\
\hline $\mathrm{E} 5 \%+\mathrm{CN} 5 \%$ & $9.2 \mathrm{a}$ & $37.6 \mathrm{a}$ & $72.7 \mathrm{a}$ & $89.6 \mathrm{a}$ & $92.9 \mathrm{a}$ & $94.7 \mathrm{a}$ \\
\hline $\mathrm{E} 7 \%+\mathrm{CN} 7 \%$ & $8.9 \mathrm{a}$ & $26.7 \mathrm{a}$ & $58.9 \mathrm{a}$ & $75.8 \mathrm{a}$ & $92.7 \mathrm{a}$ & $96.5 \mathrm{a}$ \\
\hline Dormex ${ }^{\mathrm{TM}}$ & $19.3 \mathrm{a}$ & $69.8 \mathrm{a}$ & $96.2 \mathrm{a}$ & $96.2 \mathrm{a}$ & $97.9 \mathrm{a}$ & $97.9 \mathrm{a}$ \\
\hline $\mathrm{CV} \%$ & 99.5 & 52.34 & 33.58 & 15.52 & 11.5 & 6.4 \\
\hline
\end{tabular}

Means followed by different letters in columns are statistically different by Scott-Knott test $(\mathrm{p}<0.05)$; DAA: Days after application; E: Erger; CN: Calcium Nitrate.

The fact that the control did not differ from sprouting inducers in the first year, but differed in the second year may be due to chilling accumulation. The first year had 104 chilling hours below 7.2 ${ }^{\circ} \mathrm{C}$ and 831 chilling hours below $13{ }^{\circ} \mathrm{C}$, while the second year had only 68 chilling hours below 7.2 ${ }^{\circ} \mathrm{C}$ and 766 chilling hours below $13{ }^{\circ} \mathrm{C}$ (Table 2). 'Fiano' grapevine was already cultivated in Água Doce, SC, Brazil (Malinovski, 2013) and São Joaquim, SC, Brazil (Brighenti et al., 2017) without the use of sprouting inducers, but these cities are colder than Campo Largo, PR, Brazil.

The difference between the chilling hours observed in the state of Santa Catarina when compared to those of the Campo Largo region in the state of Paraná and the satisfactory sprouting results obtained in the control may mean that the Fiano cultivar overcomes endodormancy with exposure to temperatures higher than $7.2{ }^{\circ} \mathrm{C}$ (Putti, Petri, \& Mendez, 2003). Grapevines have a high variation in the cold requirement below $7{ }^{\circ} \mathrm{C}$ (50 to 400 chilling hours), which is related to the characteristic of each cultivar (Pouget, 1963). However, due to the typical annual fluctuation in chilling accumulation in the state of Paraná (Biasi, Carvalho, \& Zanette, 2010), inductors may be necessary for years of mild winters. The application of $\operatorname{Erger}^{\mathrm{TM}}$ and potassium nitrate increased bud burst of 'Niagara Rosada' grapevine in a tropical region in the State of São Paulo, Brazil, where there is no chilling accumulation. A total of $86.1 \%$ of bud burst were obtained at 35 days after application of Erger ${ }^{\mathrm{TM}}$ at $7 \%+$ potassium nitrate at $7 \%$, while only $8.3 \%$ of the buds sprouted in the control. The application of Dormex ${ }^{\mathrm{TM}}$ at $6 \%$ resulted in a sprouting rate of $66.6 \%$, similar to the application of $\operatorname{Erger}^{\mathrm{TM}}$ at $5 \%+$ potassium nitrate at $5 \%$, which reached a value of $61.1 \%$ (Santana, 2011). The application of Dormex ${ }^{\mathrm{TM}}$ at $2 \%$ in the same grapevine cultivar promoted $93.6 \%$ of bud burst in the state of Paraná (Werle, Guimarães, Dalastra, Echer, \& Pio, 2008), 
which is similar to the result obtained for the cultivar Fiano in this study. The combination of Erger ${ }^{\mathrm{TM}}$ and calcium nitrate was efficient for sprouting buds of the 'Imperial Gala' and 'Fuji Suprema' apple trees at the same concentrations studied in this experiment (Hawerroth et al., 2010).

Table 2

Chilling hours accumulation below $7.2^{\circ} \mathrm{C}$ and $13^{\circ} \mathrm{C}$ during the autumn and winter in 2014 and 2015

\begin{tabular}{ccccc}
\hline 2014 & $\begin{array}{c}\text { Chilling hours } \\
\left(\mathrm{T} \leq 7.2^{\circ} \mathrm{C}\right) \text { during the } \\
\text { period }\end{array}$ & $\begin{array}{c}\text { Chilling hours } \\
\left(\mathrm{T} \leq 7.2^{\circ} \mathrm{C}\right) \\
\text { accumulated }\end{array}$ & $\begin{array}{c}\text { Chilling hours } \\
\left(\mathrm{T} \leq 13^{\circ} \mathrm{C}\right) \text { during the } \\
\text { period }\end{array}$ & $\begin{array}{c}\text { Chilling hours } \\
\left(\mathrm{T} \leq 13^{\circ} \mathrm{C}\right) \\
\text { accumulated }\end{array}$ \\
\hline $05 / 01-05 / 31$ & 0 & 0 & 233 & 233 \\
$06 / 01-06 / 30$ & 39 & 39 & 218 & 451 \\
$07 / 01-07 / 31$ & 63 & 102 & 353 & 804 \\
$08 / 01-08 / 05^{*}$ & 2 & 104 & 27 & 831 \\
\hline & Chilling hours & Chilling hours & Chilling hours & Chilling hours \\
2015 & $\left(\mathrm{~T} \leq 7.2^{\circ} \mathrm{C}\right)$ during the & accumulated & $\left(\mathrm{T} \leq 13^{\circ} \mathrm{C}\right)$ during the & period \\
\hline $05 / 01-05 / 31$ & period & 9 & 164 & accumulated \\
$06 / 01-06 / 30$ & 9 & 31 & 310 & 164 \\
$07 / 01-07 / 31$ & 22 & 68 & 222 & 474 \\
$08 / 01-08 / 14^{*}$ & 37 & 68 & 70 & 696 \\
\hline
\end{tabular}

*Date of sprout inducers application.

Little variation was observed in the duration of each phenological stage as a function of the application of sprouting inducers. Significant differences were observed only in the number of days between application and bud burst $(\mathrm{BBCH}$ $07)$ and in the period between maturity (BBCH 81) and harvest (BBCH 89) in the 2014/2015 cycle. The following cycle showed the only difference in the period between pea grain $(\mathrm{BBCH} 75)$ and maturation onset (BBCH 81) (Table 3). The same was observed for the degree-days since the thermal sum is proportional to the number of days of each phenological stage (Table 4).

Erger $^{\mathrm{TM}}$ at $7 \%+$ calcium nitrate at $7 \%$ caused a delay in sprouting in relation to other treatments, which did not differ from the control in the 2014/2015 cycle. Buds took 36 days after applying the products to reach the beginning of bud burst stage (BBCH 07), while buds sprouted after 22 days in the control (Table 3), resulting in a delay of two weeks. This delay in sprouting may be useful in regions with late frost occurrence, which can cause severe damage to the developing buds. This initial delay in sprouting was compensated by a reduction in the time between the inflorescence clearly visible (BBCH 53) and full flowering (BBCH 65) stages, which, although not significantly different from the other treatments, was one week shorter than in the control. Thus, flowering occurred with little variation between treatments. This result can be explained by the increased temperature during the flowering period, whose maximum temperature exceeded $25^{\circ} \mathrm{C}$ in November 2014 (Figure 1), which may have induced flowering in all plants regardless of their vegetative development. The increased air temperature is related to flowering induction (Vasconcelos, Greven, Winefield, Trought, \& Raw, 2009). After the beginning of ripening (BBCH 81), treatments with Erger ${ }^{\mathrm{TM}}$ at 5 and $7 \%$ reached the berries ripe for harvest stage $(\mathrm{BBCH} 89)$ faster than the other treatments (Table 3) and with lower thermal sum Table 4). 
Table 3

Days needed to each phonologic stage changes of 'Fiano' grapevine in Campo Largo, PR, Brazil, during the cycles 2014/2015 and 2015/2016

\begin{tabular}{|c|c|c|c|c|c|c|c|}
\hline Treatment & $\mathrm{AP}-\mathrm{BB}$ & $\mathrm{BB}-\mathrm{IV}$ & IV - FF & $\mathrm{FF}-\mathrm{FS}$ & $\mathrm{FS}-\mathrm{BP}$ & $\mathrm{BP}-\mathrm{BR}$ & $\mathrm{BR}-\mathrm{H}$ \\
\hline \multicolumn{8}{|c|}{$2014 / 2015$} \\
\hline Control & $22.00 \mathrm{~b}$ & $33.25 \mathrm{a}$ & $25.75 \mathrm{a}$ & $12.50 \mathrm{a}$ & $10.75 \mathrm{a}$ & $54.25 \mathrm{a}$ & $41.50 \mathrm{a}$ \\
\hline $\mathrm{E} 3 \%+\mathrm{CN} 3 \%$ & $26.00 \mathrm{~b}$ & $27.25 \mathrm{a}$ & $29.25 \mathrm{a}$ & $11.00 \mathrm{a}$ & $10.50 \mathrm{a}$ & $56.25 \mathrm{a}$ & $39.75 \mathrm{a}$ \\
\hline $\mathrm{E} 5 \%+\mathrm{CN} 5 \%$ & $26.00 \mathrm{~b}$ & $25.50 \mathrm{a}$ & $31.00 \mathrm{a}$ & $11.00 \mathrm{a}$ & $12.50 \mathrm{a}$ & $57.50 \mathrm{a}$ & $36.50 \mathrm{~b}$ \\
\hline $\mathrm{E} 7 \%+\mathrm{CN} 7 \%$ & $36.00 \mathrm{a}$ & $32.25 \mathrm{a}$ & $18.75 \mathrm{a}$ & $10.00 \mathrm{a}$ & $14.50 \mathrm{a}$ & $55.00 \mathrm{a}$ & $33.50 \mathrm{~b}$ \\
\hline Dormex $^{\mathrm{TM}}$ & $20.00 \mathrm{~b}$ & $28.00 \mathrm{a}$ & $30.00 \mathrm{a}$ & $12.25 \mathrm{a}$ & $10.25 \mathrm{a}$ & $59.75 \mathrm{a}$ & $39.75 \mathrm{a}$ \\
\hline $\mathrm{CV} \%$ & 16.14 & 44.61 & 35.41 & 37.76 & 54.77 & 14.44 & 8.42 \\
\hline \multicolumn{8}{|c|}{$2015 / 2016$} \\
\hline Control & $20.00 \mathrm{a}$ & $19.50 \mathrm{a}$ & $26.00 \mathrm{a}$ & $14.75 \mathrm{a}$ & $15.75 \mathrm{a}$ & $47.00 \mathrm{~b}$ & 28.00 \\
\hline $\mathrm{E} 3 \%+\mathrm{CN} 3 \%$ & $21.75 \mathrm{a}$ & $20.25 \mathrm{a}$ & $25.25 \mathrm{a}$ & $15.75 \mathrm{a}$ & $13.00 \mathrm{a}$ & $47.00 \mathrm{~b}$ & 28.00 \\
\hline $\mathrm{E} 5 \%+\mathrm{CN} 5 \%$ & $21.75 \mathrm{a}$ & $22.25 \mathrm{a}$ & $21.50 \mathrm{a}$ & $19.00 \mathrm{a}$ & $11.50 \mathrm{a}$ & $47.00 \mathrm{~b}$ & 28.00 \\
\hline $\mathrm{E} 7 \%+\mathrm{CN} 7 \%$ & $23.75 \mathrm{a}$ & $20.25 \mathrm{a}$ & $23.25 \mathrm{a}$ & $19.00 \mathrm{a}$ & $9.75 \mathrm{a}$ & $47.00 \mathrm{~b}$ & 28.00 \\
\hline Dormex ${ }^{\mathrm{TM}}$ & $14.75 \mathrm{a}$ & $20.25 \mathrm{a}$ & $23.50 \mathrm{a}$ & $19.50 \mathrm{a}$ & $14.00 \mathrm{a}$ & $51.00 \mathrm{a}$ & 28.00 \\
\hline $\mathrm{CV} \%$ & 29.88 & 30.33 & 23.79 & 20.47 & 27.15 & 4.32 & - \\
\hline
\end{tabular}

Means followed by different letters in columns are statistically different by Scott-Knott test ( $<<0.05)$; DAA: Days after application; E: ErgerTM; CN: Calcium Nitrate; AP: Application; BB: Bud Burst; IV: Inflorescence Visible; FF: Full Flowering; FS: Fruit Set; BP: Berries Pea-sized; BR: Beginning of Ripening; H: Harvest.

Table 4

Degree-days per phenological stages of 'Fiano' grapevine under Erger'TM and Dormex ${ }^{\mathrm{TM}}$ effect in Campo Largo, PR, Brazil, during the cycles 2014/2015 and 2015/2016

\begin{tabular}{|c|c|c|c|c|c|c|c|}
\hline Treatment & $\mathrm{AP}-\mathrm{BB}$ & $\mathrm{BB}-\mathrm{IV}$ & $\begin{array}{c}\text { IV }- \text { FF } \\
2014 / 2015\end{array}$ & $\mathrm{FF}-\mathrm{FS}$ & $\mathrm{FS}-\mathrm{BP}$ & $\mathrm{BP}-\mathrm{BR}$ & $\mathrm{BR}-\mathrm{H}$ \\
\hline Control & $146.35 \mathrm{~b}$ & $269.75 \mathrm{a}$ & $237.03 \mathrm{a}$ & $139.76 \mathrm{a}$ & $113.41 \mathrm{a}$ & $655.78 \mathrm{a}$ & $543.56 \mathrm{a}$ \\
\hline $\mathrm{E} 3 \%+\mathrm{CN} 3 \%$ & $169.29 \mathrm{~b}$ & $212.09 \mathrm{a}$ & $287.48 \mathrm{a}$ & $127.12 \mathrm{a}$ & $95.81 \mathrm{a}$ & $697.72 \mathrm{a}$ & $516.13 \mathrm{a}$ \\
\hline $\mathrm{E} 5 \%+\mathrm{CN} 5 \%$ & $169.29 \mathrm{~b}$ & $197.98 \mathrm{a}$ & $297.44 \mathrm{a}$ & $131.27 \mathrm{a}$ & $125.27 \mathrm{a}$ & $720.12 \mathrm{a}$ & $464.27 \mathrm{~b}$ \\
\hline $\mathrm{E} 7 \%+\mathrm{CN} 7 \%$ & $242.53 \mathrm{a}$ & $273.38 \mathrm{a}$ & $204.28 \mathrm{a}$ & $111.85 \mathrm{a}$ & $148.56 \mathrm{a}$ & $709.62 \mathrm{a}$ & $415.41 \mathrm{~b}$ \\
\hline Dormex ${ }^{\mathrm{TM}}$ & $134.88 \mathrm{~b}$ & $208.15 \mathrm{a}$ & $274.51 \mathrm{a}$ & $140.55 \mathrm{a}$ & $103.83 \mathrm{a}$ & $727.60 \mathrm{a}$ & $516.13 \mathrm{a}$ \\
\hline \multirow[t]{2}{*}{$\mathrm{CV} \%$} & 18.37 & 48.95 & 29.82 & 37.25 & 62.27 & 13.4 & 10.18 \\
\hline & & & $2015 / 2016$ & & & & \\
\hline Control & $131.43 \mathrm{a}$ & $162.00 \mathrm{a}$ & $259.97 \mathrm{a}$ & $120.01 \mathrm{a}$ & $161.31 \mathrm{a}$ & $537.40 \mathrm{~b}$ & 341.65 \\
\hline $\mathrm{E} 3 \%+\mathrm{CN} 3 \%$ & $140.67 \mathrm{a}$ & $187.24 \mathrm{a}$ & $240.95 \mathrm{a}$ & $128.96 \mathrm{a}$ & $136.90 \mathrm{a}$ & $537.40 \mathrm{~b}$ & 341.65 \\
\hline $\mathrm{E} 5 \%+\mathrm{CN} 5 \%$ & $142.38 \mathrm{a}$ & $206.15 \mathrm{a}$ & $204.87 \mathrm{a}$ & $154.25 \mathrm{a}$ & $127.07 \mathrm{a}$ & $537.40 \mathrm{~b}$ & 341.65 \\
\hline $\mathrm{E} 7 \%+\mathrm{CN} 7 \%$ & $156.42 \mathrm{a}$ & $192.11 \mathrm{a}$ & $220.34 \mathrm{a}$ & $153.45 \mathrm{a}$ & $112.40 \mathrm{a}$ & $537.40 \mathrm{~b}$ & 341.65 \\
\hline Dormex ${ }^{\mathrm{TM}}$ & $93.38 \mathrm{a}$ & $144.96 \mathrm{a}$ & $251.35 \mathrm{a}$ & $168.99 \mathrm{a}$ & $127.17 \mathrm{a}$ & $586.27 \mathrm{a}$ & 341.65 \\
\hline CV \% & 31.74 & 30.39 & 24.88 & 21.21 & 24.13 & 4.61 & - \\
\hline
\end{tabular}

Means followed by different letters in columns are statistically different by Scott-Knott test $(\mathrm{p}<0.05)$; DAA: Days after application; E: ErgerTM; CN: Calcium Nitrate; AP: Application; BB: Bud Burst; IV: Inflorescence Visible; FF: Full Flowering; FS: Fruit Set; BP: Berries Pea-sized; BR: Beginning of Ripening; H: Harvest. 


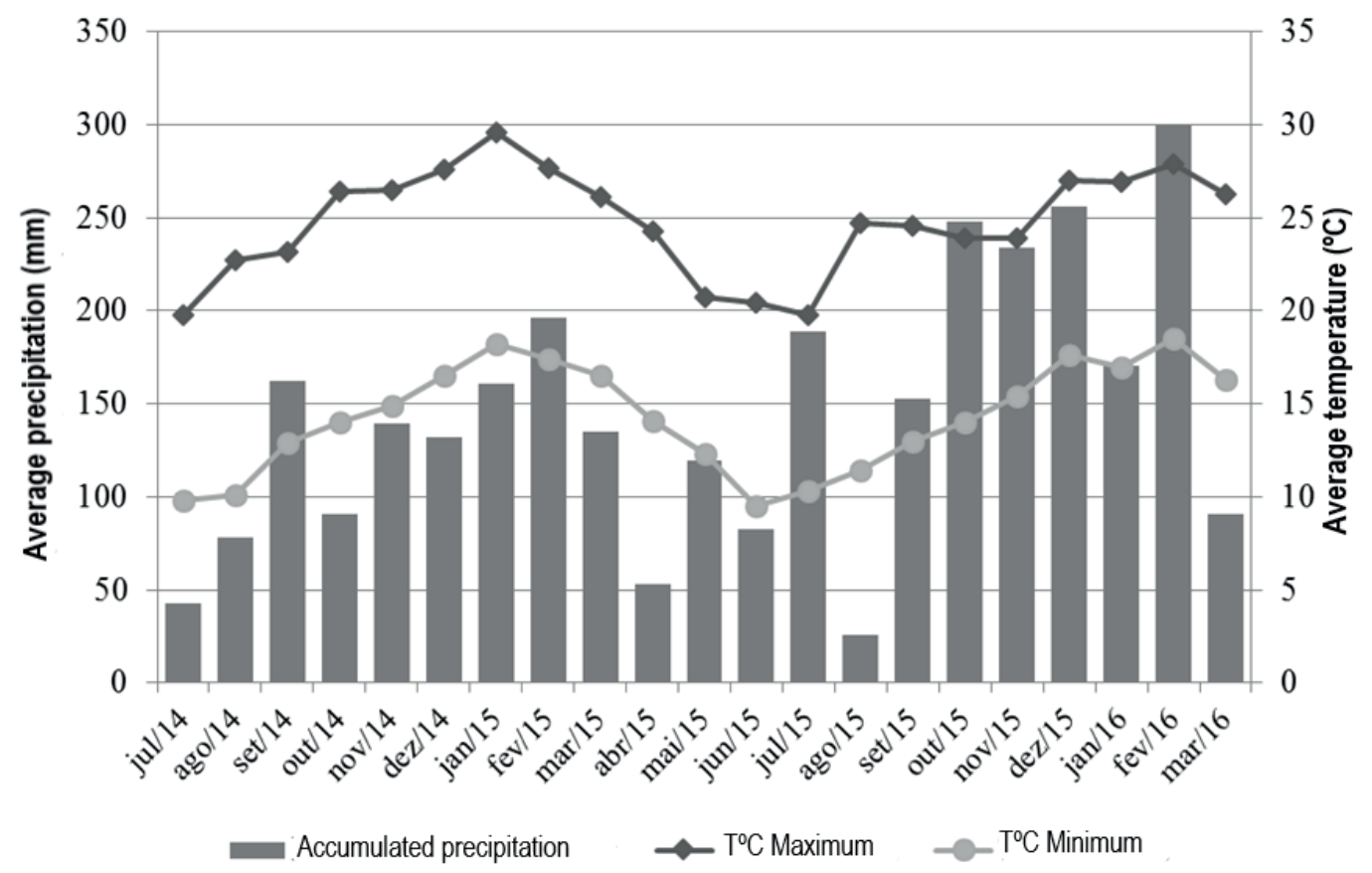

Figure 1. Average temperatures maximum and minimum and precipitation during the cycles 2014/2015 and 2015/2016 in Campo Largo, PR, Brazil.

No significant difference was observed between treatments for the beginning of sprouting in the $2015 / 2016$ cycle. The delay with the application of Erger ${ }^{\mathrm{TM}}$ at $7 \%$ + calcium nitrate at $7 \%$ was only three days in relation to the control (Table 3 ). It confirms that the response of grapevine to the application of these products depends on other factors and probably climate factors are involved since a high difference was observed in the accumulation of chilling (Table 2), precipitation, and temperatures between cycles (Figure 1).

The duration of the cycle between sprouting and harvest varied, on average, 178 days in the 2014/2015 cycle and 151 days in the 2015/2016 cycle. The cycle was shorter than that observed in Água Doce, SC, which lasted 187 days (Malinovski et al., 2016), and in São Joaquim, SC, which lasted 202 days (Brighenti et al., 2017). This difference should be a result of lower altitude and higher temperatures in Campo Largo, PR. Therefore, it is not safe to extrapolate phenological data from one region to another, but study them at each specific location due to climate differences (Roberto et al., 2005).

No significant difference was observed between treatments for all analyzed bunch variables. 'Fiano' grapevine produced, on average, 25 bunches per plant, with a mean weight of $128 \mathrm{~g}$, resulting in a production of $3.2 \mathrm{~kg}$ per plant. Berries had an average weight of $2.13 \mathrm{~g}, 13.12 \mathrm{~mm}$ wide, and $15.36 \mathrm{~mm}$ long (Table 5). The production of 'Fiano' in Campo Largo, PR, was superior when compared to that observed with 12 Italian cultivars in São Joaquim, SC, conducted under the same trellis system, with a spacing of $1.5 \mathrm{~m}$ between plants. The cultivar with the highest production per plant was 'Montepulciano,' with $3 \mathrm{~kg}$, followed by 'Sagrantino' and 'Sangiovese,' with $2.7 \mathrm{~kg}$ (Brighenti et al., 2014). 
Table 5

Bunch and berries characteristics of 'Fiano' grapevine in Campo Largo, PR, Brazil

\begin{tabular}{ccc}
\hline Characteristic & Average \pm Standard deviation & CV (\%) \\
\hline Number of bunches per plant & $25.35 \pm 7.41$ & 29.52 \\
Bunche weight $(\mathrm{g})$ & $128.55 \pm 35.14$ & 23.99 \\
Yield of bunches per plant $(\mathrm{kg})$ & $3.23 \pm 1.05$ & 25.20 \\
Bunch width $(\mathrm{cm})$ & $10.98 \pm 1.24$ & 10.89 \\
Bunch length $(\mathrm{cm})$ & $15.38 \pm 1.32$ & 5.52 \\
Number of berries per bunch & $111.88 \pm 20.83$ & 13.34 \\
Berry weight $(\mathrm{g})$ & $2.13 \pm 0.20$ & 9.05 \\
Percentage of raquis (\%) & $3.93 \pm 0.58$ & 16.67 \\
Berry width (cm) & $13.12 \pm 0.37$ & 2.20 \\
Berry length $(\mathrm{cm})$ & $15.36 \pm 0.48$ & 3.37 \\
Number of seeds per berry & $1.25 \pm 0.16$ & 11.09 \\
Seeds weight per berry (mg) & $59.67 \pm 12.57$ & 21.69 \\
\hline
\end{tabular}

'Fiano' is originated from the Campania region in Italy, characterized by warm, dry summers and moderately cold, rainy winters (Ducci \& Tranfaglia, 2008). In a study carried out with the Aglianico cultivar, in a $368-\mathrm{m}$ altitude area in this region, a high thermal amplitude was observed during the maturation period of grapes, with minimum and maximum temperatures of 9.5 and $39{ }^{\circ} \mathrm{C}$, respectively, in 2011 and 2012 (Bonfante et al., 2017). Summers are hot, but also quite rainy in the Campo Largo region, which aggravates the incidence of rot in bunches. The thermal amplitude is also smaller than that verified in the Campania region.
The cultivar Fiano presented $17.47^{\circ}$ Brix, 120.40 $\mathrm{mEq} \mathrm{L^{-1 }}$ of titratable acidity, and $\mathrm{pH} 3.17$ at the beginning of maturation in the $2014 / 2015$ cycle. The soluble solids content increased until February 10 and remained stable until harvesting, on February 18 , with $19.36^{\circ}$ Brix. These values were similar to those obtained by Malinovski (2013), Moio et al. (2012), and Scaglione, Pasquarella, Rotundo, Marone, and Nadal (2001). Acidity showed a gradual decrease until reaching $71.4 \mathrm{mEq} \mathrm{L}^{-1}$ at harvest, which was much lower than that found by Malinovski (2013). The $\mathrm{pH}$ presented a small increase, reaching 3.52 (Figure 2). 

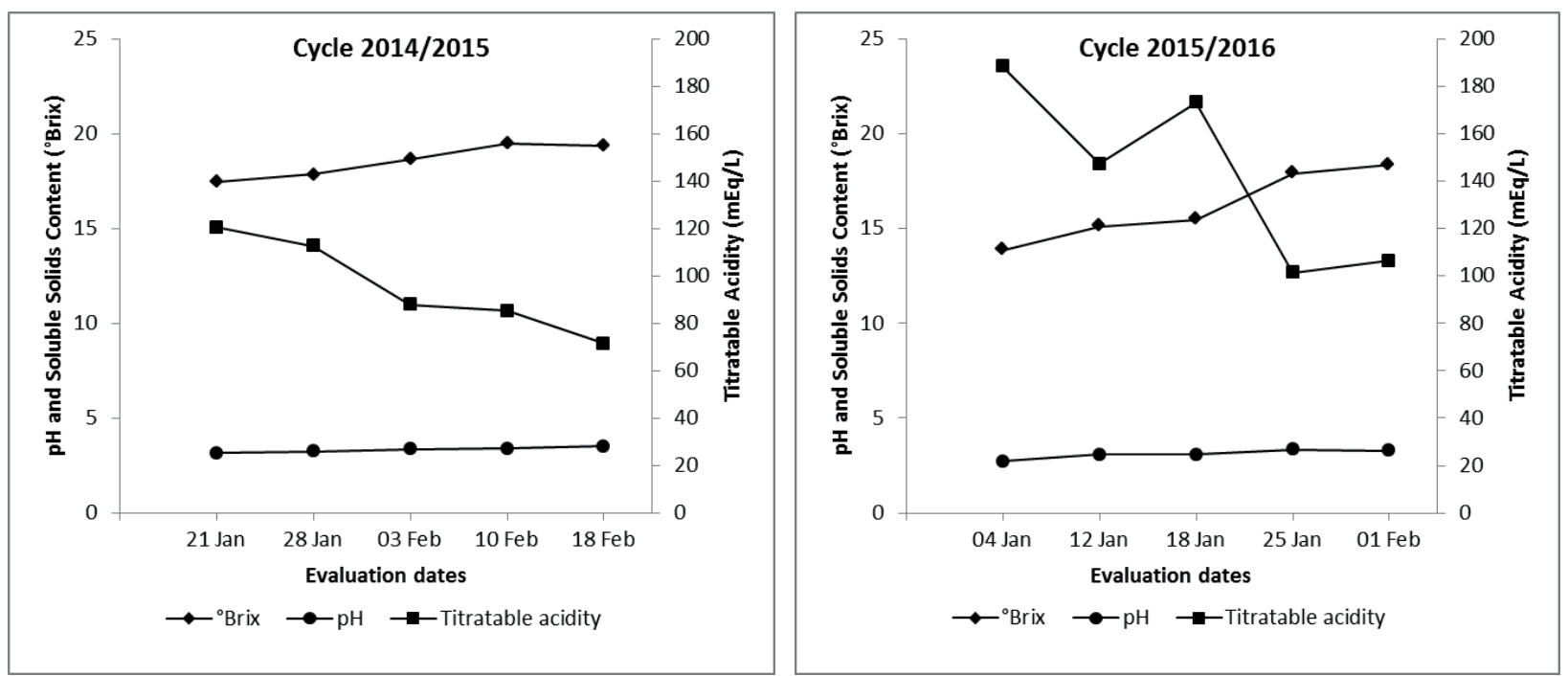

Figure 2. Evolution of soluble solids contents, titratable acidity and pH of 'Fiano' grapes in 2014/2015 and 2015/2016 cycles in Campo Largo, PR, Brazil.

In the 2015/2016 cycle, the soluble solids content also increased until reaching the highest value at harvest, with $18.33{ }^{\circ}$ Brix. Titratable acidity showed an increase from 147.2 to 173.2 $\mathrm{mEq} \mathrm{L}^{-1}$ from January 12 to 18 , decreasing again and remaining stable until harvesting on February 1, when it presented a value of $106.4 \mathrm{mEq} \mathrm{L} \mathrm{L}^{-1}$. The $\mathrm{pH}$ presented a small variation, reaching 3.29 at harvest (Figure 2). The lower soluble solids content and higher acidity in the 2015/2016 cycle were probably due to climate differences between years, as precipitation was higher and maximum temperatures were lower when compared to those observed in the previous year during berry growth in November and December (Figure 1).

\section{Conclusion}

Erger $^{\mathrm{TM}}$ application increases bud burst of 'Fiano' grapevine in years of lower accumulation of chilling hours.

Erger $^{\mathrm{TM}}$ causes a delay of sprouting mainly when applied at $7 \%$.

Erger ${ }^{\mathrm{TM}}$ concentrations ranging from 3 to $7 \%$ do not affect bunch and berry characteristics.
'Fiano' grapevine is productive and adapted to Campo Largo, PR, Brazil, with high potential for white wine production.

\section{References}

Allebrandt, R., Marcon, J. L., F', Würz, D. A., Bem, B. P., Kretzschmar, A. A., \& Rufato, L. (2017). Pruning methods on the yield performance and oenological potential of 'Nebbiolo' grapevine. Pesquisa Agropecuária Brasileira, 52(11), 1017-1022. doi: 10.1590/S0100-204X2017001100007

Biasi, L. A., Carvalho, R. I. N., \& Zanette, F. (2010). Dinâmica da dormência de gemas de videira e quivizeiro em região de baixa ocorrência de frio. Revista Brasileira de Fruticultura, 32(4), 12441249. doi: 10.1590/S0100-29452010005000118

Bonfante, A., Alfieri, S. M., Albrizio, R., Basile, A., Mascelllis, R., Gambuti, A.,... Terribile, R. (2017). Evaluation of the effects of future climate change on grape quality through a physically based model application: a case study for the Aglianico grapevine in Campania region, Italy. Agricultural Systems, 152, 100-109. doi: 10.1016/j.agsy.2016.12.009

Botelho, R. V., Pavanello, A. P., Pires, E. J. P., Terra, M. M., \& Muller, M. M. L. (2007). Effects of chilling and garlic extract on bud dormancy release in 'Cabernet Sauvignon' grapevine cuttings. American Journal of Enology and Viticulture, 58(3), 402-404. 
Brighenti, E., Casagrande, K., Cardoso, P. Z., Pasa, M. S., Ciotta, M. N., \& Brighenti, A. F. (2017). Total polyphenols contents in different grapevine varieties in highlands of southern Brazil. BIO Web of Conferences, 9, 1024. doi: 10.1051/ bioconf/20170901024

Brighenti, A. F., Silva, A. L., Brighenti, E., Porro, D., \& Stefanini, M. (2014). Desempenho vitícola de variedades autóctones italianas em condição de elevada altitude no Sul do Brasil. Pesquisa Agropecuária Brasileira, 49(6), 465-474. doi: 10.1590/S0100-204X2014000600008

Bueno, T. F., Villa, F., Rosa, D. D., \& Stumm, D. R. (2017). Uso de produto à base de alho associado à poda no desempenho de videiras finas no oeste paranaense. Revista Ceres, 64(4), 426-432. doi: 10.1590/0034-737X201764040012

Dry, P. R. (2000). Canopy management for fruitfulness. Australian Journal of Grape and Wine Research, 6(2), 109-115. doi: 10.1111/j.1755-0238.2000. tb00168.x

Ducci, D., \& Tranfaglia, G. (2008). Effects of climate change on groundwater resources in Campania (southern Italy). Geological Society, London, Special Publications, 288, 25-38. doi: 10.1144/SP288.3

Food and Agriculture Organization. (2019). Production. Crops. Retrieved from http://www.fao.org/faostat/ en/\#data/QC

Hawerroth, F. J., Petri, J. L., Leite, G. B., \& Herter, F. G. (2010). Brotação de gemas em macieiras 'Imperial Gala' e 'Fuji Suprema' pelo uso de Erger ${ }^{\circledR}$ e nitrato de cálcio. Revista Brasileira de Fruticultura, 32(2), 343-350. doi: 10.1590/S0100-29452010005000074

Instituto Adolfo Lutz. (2008). Métodos físico-químicos para análise de alimentos. São Paulo: Instituto Adolfo Lutz.

Lorenz, D. H., Eichhorn, K. W., Bleiholder, H., Klose, R., Meier, U., \& Weber, E. (1995). Growth stages of the grapevine: Phenological growth stages of the grapevine (Vitis vinifera L. ssp. vinifera) Codes and descriptions according to the extended $\mathrm{BBCH}$ scale. Australian Journal of Grape and Wine Research, 1(2), 100-110. doi: 10.1111/j.1755-0238.1995. tb00085.x

Malinovski, L. I. (2013). Comportamento viti-enológico da videira (Vitis vinifera L.) de variedades autóctones italianas na Região dos Campos de Palmas em Água Doce - SC - Brasil. Tese (Doutorado em Recursos Genéticos Vegetais) - Universidade Federal de Santa Catarina, Florianópolis, SC, Brasil.
Malinovski, L. I., Vieira, H. J., Campos, C. G. C., Stefanini, M., \& Silva, A. L. (2016). Climate and phenology: behavior of autochthonous Italian grapevine varieties in the uplands of southern Brazil. Journal of Agricultural Science, 8(5), 26-33. doi: 10.5539/jas.v8n5p26

Malinovski, L. I., Welter, L. J., Brighenti, A. F., Vieira, H. J., Guerra, M. P., \& Silva, A. L. (2012). Highlands of Santa Catarina/Brazil: a region with high potential for wine production. Acta Hortic., 931, 433-440. doi: 10.17660/ActaHortic.2012.931.51

Mello, L. M. R. (2017). Panorama da produção de uvas e vinhos no Brasil. Campo \& Negócios, 12, 54-56.

Moio, L., Genovese, A., Gambuti, A., Lamorte, S. A., Lisanti, M. T., Piombino, P., \& Ugliano, M. (2012). L'aroma dell'uva e del vino Fiano. In L. Moio (Org.). Colori; Odori ed enologia del Fiano: Sperimentazione e ricerca enologica in Campania (Chap. 4, pp. 61-62). Dragoni: Imago Editrice.

Pouget, R. (1963). Recherches physiologiques sur le repos végétatif de la vigne (Vitis vinifera $L$.) la dormance des bourgeons et le mécanisme de sa disparition. Thèse de Doctorat, Institut National de la Recherche Agronomique, Paris, Frace.

Putti, G. L., Petri, J. L., \& Mendez, M. E. (2003). Temperaturas efetivas para a dormência da macieira (Malus domestica Borkh). Revista Brasileira de Fruticultura, 25(2), 210-212. doi: 10.1590/S010029452003000200006

Roberto, S. R., Sato, A. J., Brenner, E. A., Jubileu, B. S., Santos, C. E., \& Genta, W. (2005). Caracterização da fenologia e exigência térmica (graus-dias) para a uva 'Cabernet Sauvignon' em zona subtropical. Acta Scientiarum Agronomy, 27(1), 183-187. doi: 10.4025/actasciagron.v27i1.2144

Santana, A. P. dos S. (2011). Produtos alternativos com atividade fungitóxica sobre patógenos da videira $e$ para quebra de dormência de gemas. Dissertação (Mestrado em Sistemas de Produção) - Universidade Estadual Paulista, Ilha Solteita, SP, Brasil.

Scaglione, G., Pasquarella, C., Rotundo, A., Marone, E., \& Nadal, M. (2001, novembre). Aspetti qualitativi della vendemmia meccanica in tre siti dell'Italia Meridionale. Annali di Simposio di Resultati di un triennio di attivitá sperimentale e duvulgagativa, Potenza, Italia, 5.

Vasconcelos, M. C., Greven, M., Winefield, C. S., Trought, M. C. T., \& Raw, V. (2009). The Flowering Process of Vitis vinifera: A Review. American Journal of Enology and Viticulture, 60(4), 411-434. 
Vianna, L. F., Massignan, A. M., Pandolfo, C., Dortzbach, D., \& Vieira, V. F. (2016). Caracterização agronômica e edafoclimática dos vinhedos de elevada altitude. Revista de Ciências Agroveterinárias, 15(3), 215226. doi: $10.5965 / 223811711532016215$

Villa Nova, N. A., Pedro, M. J., Jr., Pereira, A. R., \& Ometto, J. C. (1972). Estimativa de graus-dias acumulados acima de qualquer temperatura base em função das temperaturas máxima e mínima. Caderno de Ciências da Terra, 30, 1-8.
Werle, T., Guimarães, V. F., Dalastra, I. M., Echer, M. M., \& Pio, R. (2008). Influência da cianamida hidrogenada na brotação e produção da videira 'Niagara Rosada' na região oeste do Paraná. Revista Brasileira de Fruticultura, 30(1), 20-24. doi: 10.1590/S0100-29452008000100006

Würz, D. A., Marcon, J. L., F ${ }^{\circ}$, Brighenti, A. F., Allebrandt, R., Bem, B. P., Magro, M.,... Kretzschmar, A. A. (2017). Effect of shoot topping intensity on 'Cabernet Franc' grapevine maturity in high-altitude region. Pesquisa Agropecuária Brasileira, 52(10), 946-950. doi: 10.1590/S0100-204X2017001000015 